\title{
Noncytotoxic and Antitumour-Promoting Activities of Garcinia Acid Esters from Garcinia atroviridis Griff. ex T. Anders (Guttiferae)
}

\author{
Mukram M. Mackeen, ${ }^{1,2}$ Lim Y. Mooi, ${ }^{1,3}$ Mohidin Amran, ${ }^{4,5}$ Nashriyah Mat, ${ }^{6}$ \\ Nordin H. Lajis, ${ }^{4}$ and Abdul M. Ali ${ }^{1,6}$ \\ ${ }^{1}$ Department of Cell and Molecular Biology, Faculty of Biotechnology and Biomolecular Sciences, Universiti Putra Malaysia, \\ Selangor, 43400 Serdang, Malaysia \\ ${ }^{2}$ Chemistry Research Laboratory, Department of Chemistry, University of Oxford, Mansfield Road, Oxford OX1 3TA, UK \\ ${ }^{3}$ Department of Preclinical Sciences, Universiti Tunku Abdul Rahman, Lot PT21144, Jalan Sungai Long, Selangor, \\ 43000 Kajang, Malaysia \\ ${ }^{4}$ Institute of Bioscience, Universiti Putra Malaysia, Selangor, 43400 Serdang, Malaysia \\ ${ }^{5}$ Sime Darby R\&D Centre, Carey Island, Lot 2664, Jalan Pulau Carey, Selangor, 42960 Carey Island, Malaysia \\ ${ }^{6}$ Faculty of Agriculture and Biotechnology, Universiti Sultan Zainal Abidin, Gong Badak Campus, Terengganu, \\ 21300 Kuala Terengganu, Malaysia
}

Correspondence should be addressed to Abdul M. Ali, manaf@unisza.edu.my

Received 5 February 2012; Revised 11 March 2012; Accepted 13 March 2012

Academic Editor: Raffaele Capasso

Copyright (C) 2012 Mukram M. Mackeen et al. This is an open access article distributed under the Creative Commons Attribution License, which permits unrestricted use, distribution, and reproduction in any medium, provided the original work is properly cited.

\begin{abstract}
The in vitro antitumour-promoting, cytotoxic, and antioxidant activities of two ester derivatives of garcinia acid, that is, 2(butoxycarbonylmethyl)-3-butoxycarbonyl-2-hydroxy-3-propanolide (1) and 1',1"-dibutyl methyl hydroxycitrate (2), that had been previously isolated from the fruits of Garcinia atroviridis Griff. ex T. Anders (Guttiferae), were examined. Based on the inhibition of Epstein-Barr virus early antigen (EBV-EA) activation, compound $\mathbf{1}\left(\mathrm{IC}_{50}: 70 \mu \mathrm{M}\right)$ showed much higher (8-fold) antitumour-promoting activity than compound $2\left(\mathrm{IC}_{50}: 560 \mu \mathrm{M}\right)$. In addition, both compounds were nontoxic towards CEMSS (human T-lymphoblastic leukemia) cells $\left(\mathrm{CD}_{50}:>100 \mu \mathrm{M}\right)$, Raji (human B-lymphoblastoid) cells $\left(\mathrm{CD}_{50}:>600 \mu \mathrm{M}\right)$, and brine shrimp $\left(\mathrm{LD}_{50}:>300 \mu \mathrm{M}\right)$. Although the antitumour-promoting activity of compound $\mathbf{1}$ is moderate compared with the known antitumour promoter genistein, its non-toxicity suggests the potential of compound $\mathbf{1}$ and related structures as chemopreventive agents. The weak antioxidant activity displayed by both compounds also suggested that the primary antitumour-promoting mechanism of compound 1 did not involve oxidative-stress quenching.
\end{abstract}

\section{Introduction}

Garcinia atroviridis Griff. ex T. Anders (Guttiferae) is a medium-sized fruit tree endemic to Peninsular Malaysia. This species grows wild throughout Peninsular Malaysia but is also widely cultivated especially in the northern states owing to its economic and medicinal values. In folkloric medicine, G. atroviridis is used as a post-partum medication and to treat earache, throat irritation, cough, dandruff, and stomach pains associated with pregnancy. Sun-dried slices of the fruits are commercially available and are popularly used as a seasoning in curries, sour relish and also for dressing fish. The young leaves are also used for culinary purposes and as a traditional vegetable [1].

The occurrence of xanthones, benzophenones, and biflavonoids is common in the Garcinia genus [2]. To date, the metabolites that have been isolated from G. atroviridis are atroviridin (xanthone); atrovirinone and 4-methylhydroatrovirinone (prenylated quinones); atrovirisidone and atrovirisidone B (prenylated depsidones); along with the 
known metabolites morelloflavone, fukugiside, naringenin, 3,8"-binaringenin, 14-cis-docosenoic acid, garcinia acid (same as (-)-hydroxycitric acid) and its $\gamma$-lactone [3-7]. Garcinia acid, which has been primarily obtained from the Garcinia genus, is an effective inhibitor of lipogenesis with commercial and clinical applications [8]. Previously, two garcinia acid esters, namely, 2-(butoxycarbonylmethyl)-3butoxycarbonyl-2-hydroxy-3-propanolide and $1^{\prime}, 1^{\prime \prime}$-dibutyl methyl hydroxycitrate (Figure 1) had been isolated from the fruits of $G$. atroviridis, guided by antifungal activity against Cladosporium herbarum $[1,9]$. In this paper, we reported the antitumour-promoting, antioxidant and cytotoxic activities of both these compounds.

\section{Materials and Methods}

2.1. Source of Garcinia Acid Esters. The two esters derivatives of garcinia acid, 2-(butoxycarbonylmethyl)-3-butoxycarbonyl-2-hydroxy-3-propanolide (1) and $1^{\prime}, 1^{\prime \prime}$-dibutyl methyl hydroxycitrate (2), were available from our previous isolation of these compounds from Garcinia atroviridis Griff. ex T. Anders (Guttiferae). Details of the isolation and identification were described in [1].

2.2. Culture of Cells. The CEM-SS (human T-lymphoblastic leukemia) cell line was obtained from the National Cancer Institute, USA, and the Raji (human B-lymphoblastoid) cell line was provided by Prof. K. Koshimizu, Kinki University, Japan. Cells were cultured in RPMI-1640 (Sigma, USA) medium with $10 \% \mathrm{v} / \mathrm{v}$ foetal calf serum (Sera Lab, UK), $100 \mathrm{IU} / \mathrm{mL}$ penicillin (Sigma, USA) and $100 \mu \mathrm{g} / \mathrm{mL}$ streptomycin (Sigma, USA) as a complete growth medium (CGM). Cells were maintained in $25 \mathrm{~cm}^{2}$ flask with $10 \mathrm{~mL}$ of $\mathrm{CGM}$ at $37^{\circ} \mathrm{C}$ with $5 \% \mathrm{CO}_{2}$. Every three days the cells were subcultured by splitting the culture with fresh CGM at a ratio of $1: 4[10]$.

2.3. MTT Cytotoxicity Assay. Cytotoxicity was determined using the MTT assay as reported by Ali et al. [10]. Varying concentrations of the test compounds were prepared from the stock solutions by serial dilution in RPMI-1640 to give a volume of $100 \mu \mathrm{L}$ in each well of a microtiter plate (96well) as described before. Each well was filled with $100 \mu \mathrm{l}$ of CEM-SS cell suspension in CGM at 1-2 $\times 10^{5}$ cells $/ \mathrm{mL}$. Controls that contained only CEM-SS cells were included for each sample. The assay for each concentration of extract was performed in triplicate and the culture plates were kept at $37^{\circ} \mathrm{C}$ with $5 \%(\mathrm{v} / \mathrm{v}) \mathrm{CO}_{2}$ for three days. After $72 \mathrm{~h}$ of incubation, $100 \mu \mathrm{L}$ of medium was removed from each well. Subsequently, $20 \mu \mathrm{L}$ of $0.5 \% \mathrm{w} / \mathrm{v}$ MTT (Sigma, USA) dissolved in phosphate buffer saline was added to each well and allowed to incubate for further $4 \mathrm{~h}$. After $4 \mathrm{~h}$ of incubation, $100 \mu \mathrm{L}$ of $1 \mathrm{~N}$ hydrochloric acid: isopropanol $(1: 24)$ was added to each well and vigorously mixed to dissolve the formazan crystals. Absorbance values at $550 \mathrm{~nm}$ were measured with a microplate reader (Bio Tek EL 340, USA) after background subtraction at $630 \mathrm{~nm}$. Cytotoxicity was expressed as $\mathrm{CD}_{50}$, that is, the concentration to reduce

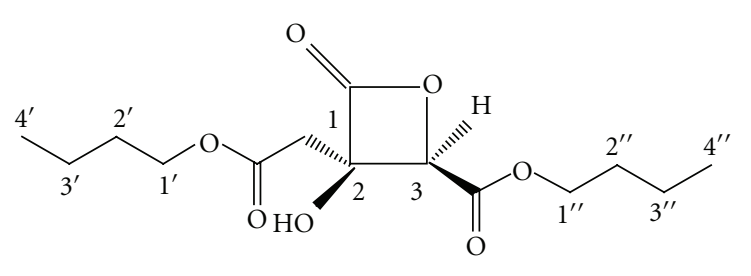

1

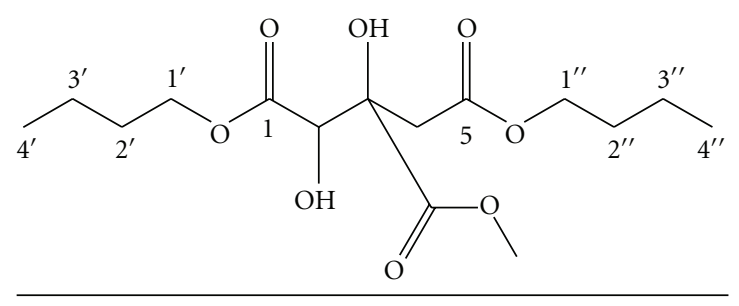

2

FIGURE 1: The structures of the compound 1 (2-(butoxycarbonylmethyl)-3-butoxycarbonyl-2-hydroxy-3-propanolide) and compound $2\left(1^{\prime}, 1^{\prime \prime}\right.$-dibutyl methyl hydroxycitrate).

the absorbance of treated cells by $50 \%$ with reference to the control (untreated cells).

2.4. Brine Shrimp Lethality/Toxicity Assay. Brine shrimp (Artemia saline Leach) eggs (Gold Eagle, USA) were placed in a hatching tank containing sea water for $48 \mathrm{~h}$ [11]. Each compound $(6 \mu \mathrm{mol})$ was dissolved in $0.2 \mathrm{~mL}$ methylene chloride:methanol $(1: 1)$ to prepare a stock solution of $30 \mathrm{mM}$. From the stock solutions, $50 \mu \mathrm{L}$ was transferred to different vials and allowed to evaporate. After evaporation, $5 \mathrm{~mL}$ of brine was added to each vial in triplicate to prepare a preliminary test concentration corresponding to $300 \mu \mathrm{M}$. Ten shrimp nauplii were added to each vial (30 shrimps per concentration). The number of survivors out of 30 shrimps per concentration was recorded.

2.5. In Vitro Antitumour-Promoting Assay. The inhibition of Epstein-Barr virus (EBV) activation was used to evaluate in vitro antitumour-promoting activity [12]. Raji cells were incubated for $48 \mathrm{~h}$ at $37^{\circ} \mathrm{C}$ under $5 \% \mathrm{CO}_{2}$ in $1 \mathrm{~mL}\left(\sim 5 \times 10^{5}\right.$ cells $)$ of RPMI-1640 medium containing $3 \mathrm{mM}$ sodium $n$-butyrate (Nacarai Tesque, Japan), $50 \mathrm{nM}$ phorbol 12-myristate 13-acetate (PMA) (Sigma, USA) and the test compounds $(600 \mu \mathrm{M})$ per well of a 24 -well plate. Conventional indirect immunofluorescence staining of early antigen (EA) with high-titre EA-positive serum (EA titre $1: 1,280)$ obtained from nasopharyngeal carcinoma (NPC) patients ( $1: 20$ serum dilution) followed by a $1: 30$ dilution of fluorescein-isothiocyanate-(FITC-)labeled IgG (Sigma, USA) was used to measure EBV activation. The ratio of EAinduced cells to the control experiments only with sodium $n$-butyrate and PMA was around 50\%. The test compounds showing antitumour-promoting activity were serially diluted (2-fold) to determine the $\mathrm{IC}_{50}$ values. 


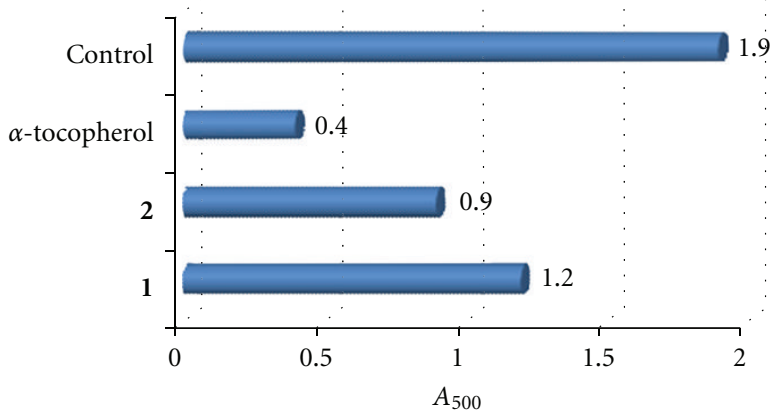

(i)

(a)

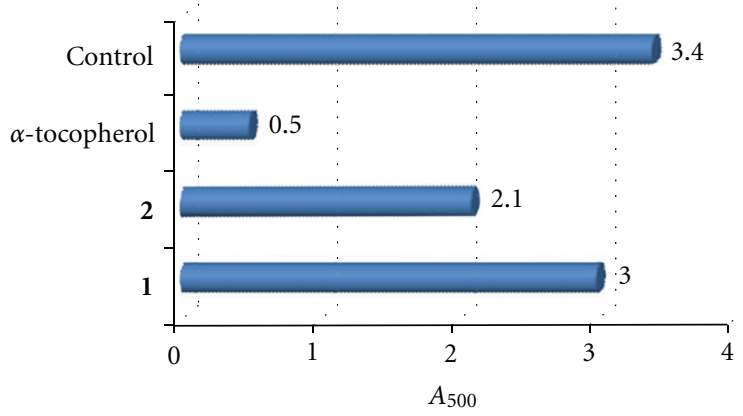

(i)

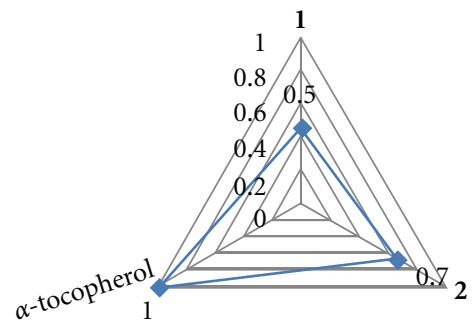

(ii)

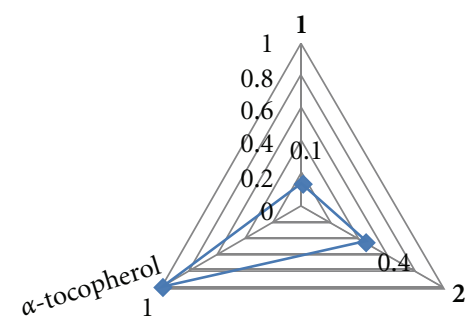

(ii)

(b)

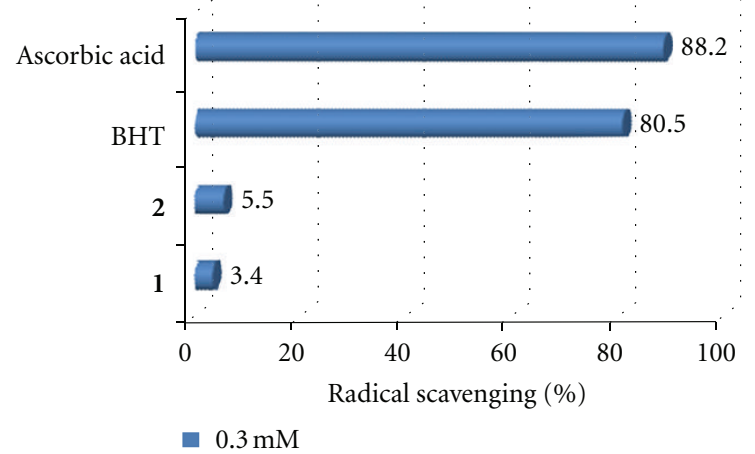

(c)

FIgURE 2: Antioxidant activities of compounds 1 and 2. (a) FTC assay (i) absorbance at $500 \mathrm{~nm}$, (ii) ratios of antioxidant values normalized to $\alpha$-tocopherol. (b) TBA assay (i) absorbance at $532 \mathrm{~nm}$, (ii) ratios of antioxidant values normalized to $\alpha$-tocopherol. (c) DPPH assay. The sample test concentrations in (a) to (c) are $0.6 \mathrm{mM}, 0.2 \mathrm{mM}$, and $0.3 \mathrm{mM}$, respectively. Assays were carried out in triplicate and averaged ( \pm 0.1 absorbance units).

\subsection{Antioxidant Assays}

2.6.1. Ferric Thiocyanate (FTC) Method. A screw-cap vial $(\varnothing 38 \times 75 \mathrm{~mm})$ containing a mixture of $4 \mathrm{mg}(4 \mathrm{~mL})$ of a sample (final concentration, $0.02 \%$ ) in $99.5 \%$ ethanol, $4.1 \mathrm{~mL}$ of $2.5 \%$ linoleic acid (TCL, Japan) in $99.5 \%$ ethanol, $8.0 \mathrm{~mL}$ of $0.05 \mathrm{M}$ phosphate buffer $(\mathrm{pH} 7.0)$, and $3.9 \mathrm{~mL}$ of water was placed in an oven at $40^{\circ} \mathrm{C}$ in the dark [13]. To $0.1 \mathrm{~mL}$ of this mixture, $9.7 \mathrm{~mL}$ of $75 \%(\mathrm{v} / \mathrm{v})$ ethanol and $0.1 \mathrm{~mL}$ of $30 \%$ ammonium thiocyanate (Wako, Japan) were added. Three minutes after the addition of $0.1 \mathrm{~mL}$ of
$2 \times 10^{-2} \mathrm{M}$ ferrous chloride (Merck, Germany) in 3.5\% hydrochloric acid to the reaction mixture, the absorbance was measured at $500 \mathrm{~nm}$ (Spectronic 20D+, USA) each $24 \mathrm{~h}$ until one day after absorbance of the control reached its maximum value. Antioxidant activity was represented by the absorbance readings on the final day of the assay (7th day) (average of triplicates).

2.6.2. Thiobarbituric Acid (TBA) Method. Two $\mathrm{mL}$ of $20 \%$ trichloroacetic acid (Fluka, Switzerland) and $2 \mathrm{~mL}$ of $0.67 \%$ 
TBA (Wako, Japan) solutions were added to $2.0 \mathrm{~mL}$ from the mixture (containing sample) prepared in the FTC method [13]. This mixture was kept in a water bath $\left(100^{\circ} \mathrm{C}\right)$ for $10 \mathrm{~min}$ and, after cooling to room temperature, was centrifuged at $3000 \mathrm{rpm}$ for $20 \mathrm{~min}$. Antioxidant activity was based on the absorbance of the supernatant at $532 \mathrm{~nm}$ wavelength on the final day of the FTC assay (average of triplicates).

2.6.3. Radical Scavenging Method. The methanol solution of 2,2-diphenyl-1-picrylhydrazyl hydrate (DPPH) (Aldrich Chem. Co., USA) radicals $(1 \mathrm{~mL}, 0.3 \mathrm{mM})$ was added to each sample ( $1 \mathrm{mM}, 0.5 \mathrm{~mL})$ and was shaken vigorously [14]. The absorbance of each sample was measured at $517 \mathrm{~nm}$ after allowing it to stand for $30 \mathrm{~min}$. Each sample (final concentration, $0.3 \mathrm{mM}$ ) was assayed in triplicate and averaged. Standard antioxidants, that is, butylated hydroxytoluene (BHT) and ascorbic acid, were used as positive controls.

\section{Results and Discussion}

In the antitumour-promoting assay, compound 1, a $\beta$ lactone, strongly inhibited ( $\left.\mathrm{IC}_{50}: 70 \mu \mathrm{M}\right) \mathrm{EBV}$ activation compared with compound 2 ( $\left.\mathrm{IC}_{50}: 560 \mu \mathrm{M}\right)$. The $\mathrm{IC}_{50}$ of 1 was almost five-fold higher than the value of the crude fruit extract $\left(\mathrm{IC}_{50}: 97 \mu \mathrm{g} / \mathrm{mL}\right)$. Compounds 1 and 2 were considered as nontoxic against CEM-SS and Raji cells $\left(\mathrm{CD}_{50}:>100 \mu \mathrm{M}\right)$. Both compounds were also inactive ( $\mathrm{LC}_{50}$ : $>300 \mu \mathrm{M})$ in the brine shrimp lethality assay that is used as an in vivo surrogate model for cytotoxicity. The antitumourpromoting activity of $\mathbf{1}$ was noteworthy because of its noncytotoxicity although it did not inhibit EBV activation as strongly as the known antitumour-promoter, genistein $\left(\mathrm{IC}_{50}: \sim 20 \mu \mathrm{M}\right)$, which is cytotoxic $[15,16]$. Since inhibition towards EBV-EA activation has been demonstrated to closely parallel in vivo antitumour promotion [17], compound 1 has the potential as a chemopreventive agent.

The antioxidant assays performed on both compounds showed weak activity that was slightly higher than the control. Compounds 2 and 1, respectively, reduced oxidant activity by 36 and $11 \%$ in the FTC assay (Figure 2(a)), 53 and $37 \%$ in the TBA assay (Figure 2(b)), and 5.5 and $3.4 \%$ in the DPPH assay (Figure 2(c)) but were weaker than the positive control(s) especially in the radical scavenging assay. It appeared that both these compounds were more effective inhibitors against late-stage oxidation as evidenced by the stronger antioxidant activity in the TBA assay than the FTC assay. The low antioxidant activity of both compounds ruled out the influence of oxidative-stress quenching as the dominant mechanism of action responsible for the antitumour-promoting activity of the $\beta$-lactone, although this mechanism is closely associated with antitumourpromoting activity [18]. This was further confirmed by the recurring trend of $\mathbf{2}$ showing higher activity than $\mathbf{1}$ in all the antioxidant assays whereas stronger antitumour-promoting activity was displayed by 1 than 2 .

\section{Conclusions}

Of the two new ester derivatives of garcinia acid, that is, 2-(butoxycarbonylmethyl)-3-butoxycarbonyl-2-hydroxy3-propanolide (1) and $1^{\prime}, 1^{\prime \prime}$-dibutyl methyl hydroxycitrate (2), previously isolated from the fruits of Garcinia atroviridis, only compound $\mathbf{1}$ showed antitumour-promoting activity although both compounds were neither toxic against the cells tested and brine shrimp nor were particularly antioxidant. This suggested the potential of compound $\mathbf{1}$ and related structures as noncytotoxic chemopreventive agents.

\section{Acknowledgment}

The authors would like to acknowledge the Ministry of Science, Technology and Innovation of Malaysia for funding this project.

\section{References}

[1] M. M. Mackeen, A. M. Ali, N. H. Lajis et al., "Antimicrobial, antioxidant, antitumour-promoting and cytotoxic activities of different plant part extracts of Garcinia atroviridis Griff. ex T. Anders," Journal of Ethnopharmacology, vol. 72, no. 3, pp. 395402, 2000.

[2] P. G. Waterman and R. A. Hussain, "Systematic significance of xanthones, benzophenones and biflavonoids in Garcinia," Biochemical Systematics and Ecology, vol. 11, no. 1, pp. 21-28, 1983.

[3] Y. S. Lewis and S. Neelakantan, “(-)-Hydroxycitric acidthe principal acid in the fruits of Garcinia cambogia desr," Phytochemistry, vol. 4, no. 4, pp. 619-625, 1965.

[4] J. Kosin, N. Ruangrungsi, C. Ito, and H. Furukawa, "A xanthone from Garcinia atroviridis," Phytochemistry, vol. 47, no. 6, pp. 1167-1168, 1998.

[5] D. Permana, N. H. Lajis, M. M. Mackeen et al., "Isolation and bioactivities of constitutents of the roots of Garcinia atroviridis," Journal of Natural Products, vol. 64, no. 7, pp. 976979, 2001.

[6] D. Permana, N. H. Lajis, K. Shaari et al., "A new prenylated hydroquinone from the roots of Garcinia atroviridis Griff ex T. Anders (Guttiferae)," Zeitschrift für Naturforschung, vol. 58, no. 4, pp. 332-335, 2003.

[7] D. Permana, F. Abas, Maulidiani et al., "Atrovirisidone B, a new prenylated depsidone with cytotoxic property from the roots of Garcinia atroviridis," Zeitschrift für Naturforschung, vol. 60, no. 7-8, pp. 523-526, 2005.

[8] B. S. Jena, G. K. Jayaprakasha, R. P. Singh, and K. K. Sakariah, "Chemistry and biochemistry of (-)-hydroxycitric acid from Garcinia," Journal of Agricultural and Food Chemistry, vol. 50, no. 1, pp. 10-22, 2002.

[9] M. M. Mackeen, A. M. Ali, N. H. Lajis, K. Kawazu, H. Kikuzaki, and N. Nakatani, "Antifungal Garcinia acid esters from the fruits of Garcinia atroviridis," Zeitschrift für Naturforschung, vol. 57, no. 3-4, pp. 291-295, 2002.

[10] A. M. Ali, M. M. Mackeen, S. H. El-Sharkawy et al., "Antiviral and cytotoxic activities of some plants used in Malaysian indigenous medicine," Pertanika Journal of Tropical Agricultural Science, vol. 19, no. 2, pp. 129-136, 1996.

[11] B. N. Meyer, N. R. Ferrign, J. E. Putnam et al., "Brine shrimp: a convenient general bioassay for active plant constituents," Planta Medica, vol. 45, no. 5, pp. 31-34, 1982. 
[12] L. Y. Mooi, N. A. Wahab, N. H. Lajis, and A. M. Ali, "Chemopreventive properties of phytosterols and maslinic acid extracted from Coleus tuberosus in inhibiting the expression of EBV early-antigen in Raji cells," Chemistry and Biodiversity, vol. 7, no. 5, pp. 1267-1275, 2010.

[13] R. Ahmad, A. M. Ali, D. A. Israf, N. H. Ismail, K. Shaari, and N. H. Lajis, "Antioxidant, radical-scavenging, anti-inflammatory, cytotoxic and antibacterial activities of methanolic extracts of some Hedyotis species," Life Sciences, vol. 76, no. 17, pp. 19531964, 2005.

[14] G. C. Yen and C. L. Hsieh, "Antioxidant effects of dopamine and related compounds," Bioscience, Biotechnology and Biochemistry, vol. 61, no. 10, pp. 1646-1649, 1997.

[15] A. Murakami, W. Kuki, Y. Takahashi et al., "Auraptene, a citrus coumarin, inhibits 12-O-tetradecanoylphorbol-13acetate-induced tumor promotion in ICR mouse skin, possibly through suppression of superoxide generation in leukocytes," Japanese Journal of Cancer Research, vol. 88, no. 5, pp. 443-452, 1997.

[16] J. B. White, J. Beckford, S. Yadegarynia, N. Ngo, T. Lialiutska, and M. d'Alarcao, "Some natural flavonoids are competitive inhibitors of caspase-1, -3 and -7 despite their cellular toxicity," Food Chemistry, vol. 131, no. 4, pp. 1453-1459, 2012.

[17] T. Konoshima, M. Takasaki, H. Tokuda et al., "Anti-tumorpromoting activities of triterpenoids from ferns. I," Biological and Pharmaceutical Bulletin, vol. 19, no. 7, pp. 962-965, 1996.

[18] K. Yoshioka, T. Deng, M. Cavigelli, and M. Karin, "Antitumor promotion by phenolic antioxidants: inhibition of AP-1 activity through induction of Fra expression," Proceedings of the National Academy of Sciences of the United States of America, vol. 92, no. 11, pp. 4972-4976, 1995. 


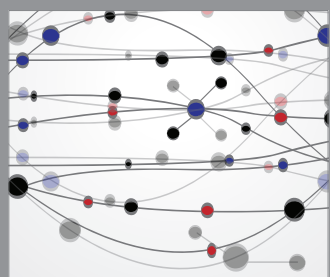

The Scientific World Journal
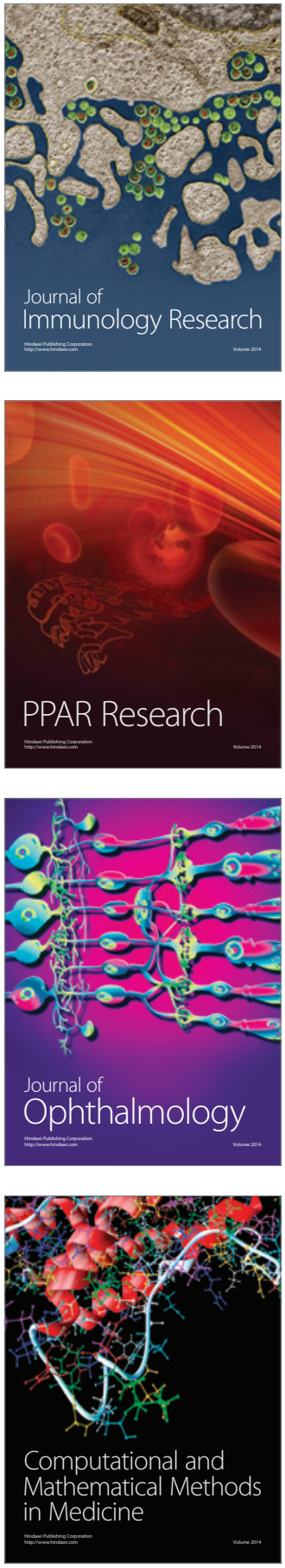

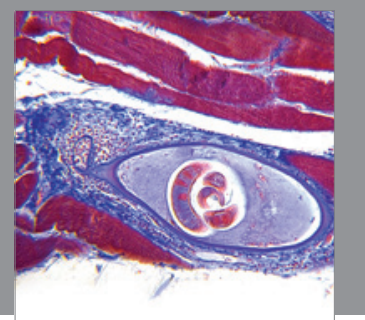

Gastroenterology

Research and Practice
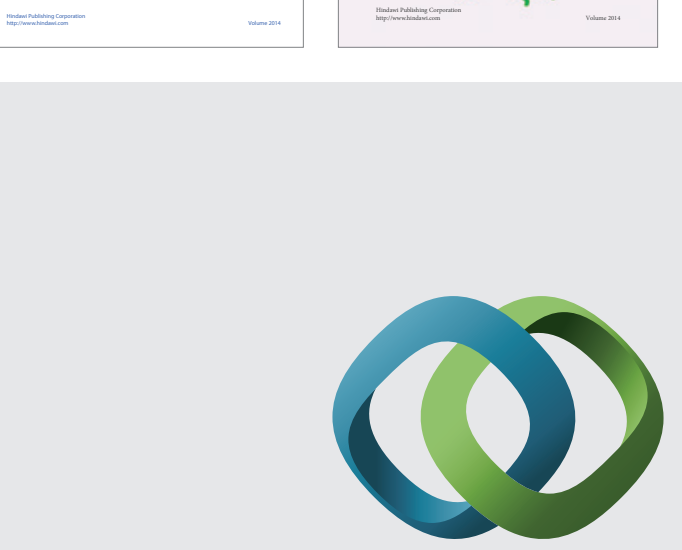

\section{Hindawi}

Submit your manuscripts at

http://www.hindawi.com
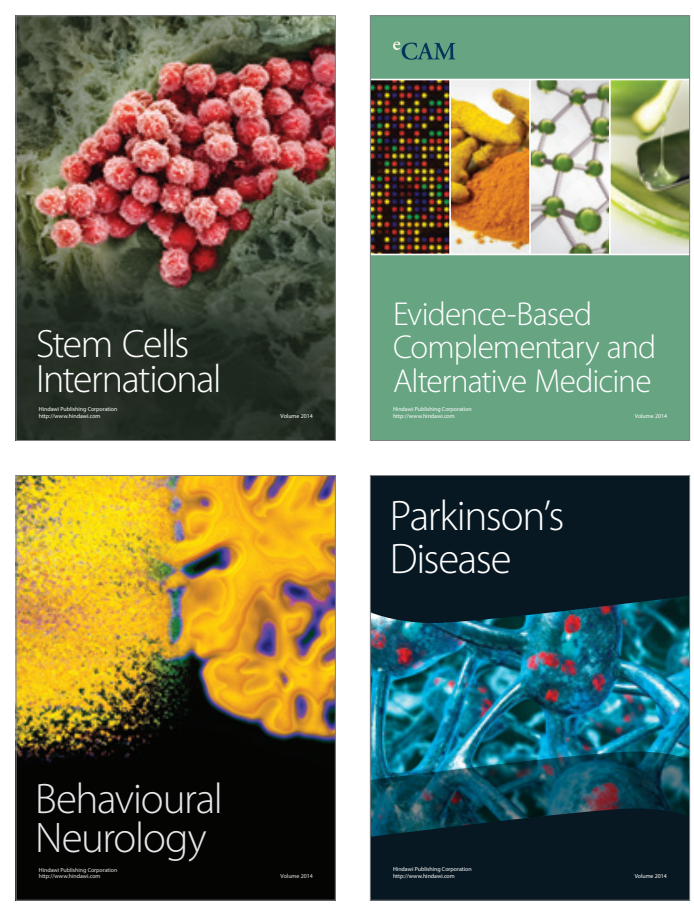

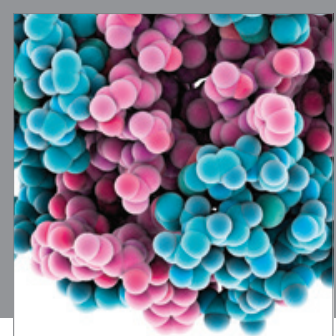

Journal of
Diabetes Research

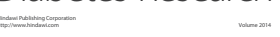

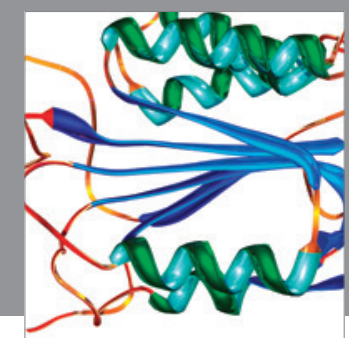

Disease Markers
